\title{
RELIABILITY OF DEPRECIATED REPLACEMENT COST TO OTHER METHODS IN VALUATION OF RELIGIOUS PROPERTY, A CASE STUDY OF ANSARUDEEN MOSQUE, ILORIN METROPOLIS
}

\author{
Sakariyau Jamiu Kayode, \\ ${ }^{1}$ Department of Estate Management and Valuation, Faculty of Environmental Technology, Abubakar \\ Tafawa Balewa University, Bauchi, Bauchi State Nigeria \\ Ajibade Rasheed Kayode, \\ ${ }^{2}$ Department of Estate Management and Valuation, Kwara State Polytechnic, \\ Ilorin, Kwara State Nigeria \\ AbdulAkeem Olasunkanmi Otunola, \\ ${ }^{3}$ Department of Estate Management and Valuation, Federal Polytechnic, \\ Offa, P.M.B. 420. Offa, Kwara State, Nigeria \\ Olatunji Olarewaju Samson, \\ ${ }^{4}$ Department of Estate Management and Valuation, Kwara State Polytechnic, \\ Ilorin Kwara State, Nigeria
}

\begin{abstract}
Mosque valuation is a highly specialized method of real estate appraisal that necessitates not only a detailed understanding of the many concepts and procedures of general appraising, but also an in-depth understanding and expertise in order to arrive at an accurate estimate of market value. Using cross-sectional statistics, this study investigates the reliability of depreciated replacement cost in valuing specialized property. For the purpose of gathering data for this analysis, two separate sets of questionnaires were used. The first questionnaires were distributed to a licensed estate surveying firm in Ilorin, Kwara State. The Mosque Committee, on the other hand, received the other collection of questionnaires. The questionnaire's questions delved into the biographical details of the Registered Estate Surveyors. Descriptive statistics were used to interpret the data. Depreciated Replacement Cost is the most accurate method of valuation of Specialized Property, the Study revealed that, due
\end{abstract}

to the specific nature of Specialized Property, such as the lack of rental evidence, the infrequency with which it is sold or rented, and the fact that it is not commonly used for other purposes. To save valuers a lot of tears, guidelines on unit cost of construction for buildings and depreciation should be made available.

Keywords: Valuation, Depreciated Replacement Cost, Religious Property, Ilorin, Nigeria.

\section{INTRODUCTION}

Valuation is "the art and science of calculating the value a particular interest in property for a specific purpose at a particular time, considering all the attributes of the property and also all the essential economic factors, including the variety of alternative investments (Millington, 1988). Valuation, being the practice, science and knack of estimating the financial attraction of interest in property. Valuation 
is thus that art of establishing an outlook of value for an interest in land and landed property/real estate (Ogunba, 2013). It is an art because it involves the use of valuer's hunch, instinct, practice and judgment. This is why property valuation is to a large extent subjective as it depends on valuer's anticipation about the future, his understanding of the laid down preposition as well as valuer's dexterousness in interpreting relevant facts and underlying assumptions to establish a specified value for the property (Babawale, 2009). Depreciated Replacement Cost Method is usually used for property that rarely changes hand in the property Market such as Town Hall, School and other Public Properties of non profit making (Onyejiaka, Oladejo, \& Emoh, 2015). In the parlance of Assets Valuation, Contractors Method is also referred to as the Depreciated Replacement Cost (DRC) Method (Mackmin, \& Sams, 2012)

Specialized Properties referred to certain classes of Proprietary lands Units which fall outside the general classes of commercial and residential properties which possess no comparables in the market upon which a valuation could readily be carried out (Parr, 2018). RICS (2005) maintain that such properties that are rarely ever sold in the market, except by way of sale of the business or entity of which it is part, due to specialities arising from its specialized nature and design its configuration, size, location and otherwise. Mosque is typically categorised as special purpose properties. Their unique design is intended to meet the needs of a specific group or purpose, they be short of adaptability to other, more conventional uses, and appraisals of religious Property incorporate only the cost method to value. With the partial market sales data and the reducing reliability of estimating depreciation as the property age increases, the overall sort of value estimated by professional appraisers on a religious property tends to be broad, The valuation approach generally adopted in the estimating their value is the Depreciated Replacement Cost Method. Thus, this study attempts to examine the reliability of Depreciated Replacement Cost approach to other methods in the valuation of Mosque as a Specialized Property in Ilorin, Kwara State.

\subsection{Statement of the Problem}

Valuing specialized properties can be difficult. Because of their peculiar existence and the fact that they are rarely or never sold. They still lack rental evidence and comparables aside from these two data. (Wyatt, 2013). That is, there aren't enough sales in a fairly specified market region, or there isn't enough specific details about current sales to make necessary changes to come to a fair and valuable conclusion.
(Wyatt, 2013). The current body of knowledge advocates the use of Depreciated Replacement Cost method in arriving at the value of Specialized Properties which is based on the assumption that value can be equated to cost and used where information on recent transaction is insufficient. However, at the foregoing, many researches have been conducted on the widespread use of Depreciated Replacement Cost Valuation over Investment Method Valuation. As a result, a void in the literature has been established. Therefore, this paper attempt to examine the reliability of replacement cost approach to other methods in valuation of Ansaruddeen Mosque in Kwara State.

\subsection{Aim of the Study}

The aim of the study is to examine the reliability of depreciated replacement cost method in the valuation of specialized property using Cross Sectional Survey with the view of examining its reliability on valuation of Ansarudeen Mosque Ilorin, Kwara State and fill the vital gap left by the previous scholar.

\subsection{Research Questions}

i. What method of Valuation is most appropriate for valuing Specialized Property?

ii. How does the value of Ansarudeen Mosque be determined using Depreciated Replacement Cost Method of valuation?

iii. What are challenges associated with valuation of Specialized Property?

\subsection{Objectives of the Study}

To achieve this aim, the following objectives were formulated.

i. To determine what method is most appropriate for valuing Specialized Property.

ii. To determine the value of Ansaru-deen Mosque Ilorin, Kwara State using Contractor Cost Method of Valuation.

iii. To investigate the challenges associated with valuation of Specialized Property.

\section{LITERATURE REVIEW}

\section{REVIEW OF LITERATURE ON DEPRECIATED REPLACEMENT COST METHOD}

Ifediora (2009) maintained that the cost method is a method of determining the value of a property by considering the cost of replacing it or obtaining an acceptable substitute. In other words, Fourcade 


\section{International Journal of Engineering Applied Sciences and Technology, 2021 Vol. 6, Issue 2, ISSN No. 2455-2143, Pages 31-38 \\ Published Online June 2021 in IJEAST (http://www.ijeast.com)}

(2011) stress the fact that the method "seeks to calculate the value of property by aggregating the costs involved in its creation," The value of the property is arrived at from the value of substitute site with the cost of building (Johnson, Davies and Shapiri, 2000). Hamilton (2013) asserted that the Institutional investors almost uniformly use the income method to estimating the Market Value of Property Investments when valuing incomeproducing properties. In the same vein Kuye (2000) and Carson (2012) remarked that Valuers should use investment approaches when valuing incoming generating properties since they are the most effective approach.

Abidoye, Junge, Lam, Oyedokun and Tipping (2019) investigated the Investment Property Paradigm Change In Lagos, valuation theory is put into motion. The data for the study came from secondary sources and was collected using systematic questionnaires. The findings indicate that most appraisers use the replacement cost approach when valuing incomegenerating properties. Babawale, Koleoso and Otegbulu, (2012) present empirical data on the applicability of the investment method of valuation on residential properties in the Lagos Metropolitan Area. According to Bellman and Lind (2019) the foundation of valuation is comparison. According to Fisher (2002), the most common method of valuation among valuers in land reference cases is the comparative method.

Ellsworth (2001) is of the opinion that the sales comparison approach (comparative method) should be seen as a valuation benchmark and a pillar of the appraisal profession. Babawale and Oyalowo (2011) asserted that the Comparative Method of Valuation appears to be the best real estate valuation exercise when values and other comparables are identical or slightly different. He went on to say that every piece of land or real estate is special and can never be exactly the same, taking into account the location, physical state, tenure, use intent, and transaction date. He emphasized the importance of employing this method. Bello and Bello (2007) stated that, The depreciated replacement cost method of valuation provides figures that are similar to market values in the current Nigerian situation, making it a more practical and appropriate method of valuing assets in the current economic situation.

According to Baum, Crosby and Devaney (2021) The Profit Method calculation necessitates estimating the property's average annual gross earnings and deducting working expenses (excluding rent) and a sum for the occupier's remuneration, including interest on the capital he has invested in the company. The remaining amount reflects the annual rent available, which is then capitalized by an appropriate amount. Profit method of valuation is often applied to properties with trading benefits. Ifediora (2009) in his description and conclusion on the cost method, he said that it is "a very useful tool in the appraisal process," but only in the hands of a knowledgeable and professional appraiser. The Depreciated Replacement Cost Method of Valuation is not without flaws, and as a result, it has been widely criticized. The complexity of calculating depreciation is a notable example of its fallacy. From the foregoing, it is suffice to state that none or only few of this studies mentioned above captured the reliability of the depreciated replacement cost method to other methods in the valuation of Ansarudeen Mosque. Thus, a research gap worthy of investigation has been identified. This, research, therefore, attempts to explore and uncover the above missing gap.

\section{RESEARCH METHODOLOGY}

A field survey research approach was adopted for the study. Data were collected through the use of a wellstructured questionnaire containing close-ended questions (for ease of analysis). The questionnaire was designed for the registered Estate Surveying and Valuation firm in the study area using five-point likert scale. A total of twenty (20) copies of the questionnaires were administered on randomly selected residents within the study area, in which Out of the 20 questionnaires administered 15 valid copies were retrieved. Mean ranking were used to measure the degree of reliability of Depreciated Cost Method of valuation to other method of Valuation. On the other hand, two Questionnaires administered to the Mosque Committee were all returned.

Table1: Demographic Data of the Respondents

\section{RESULT AND DISCUSSIONS}

Gender

$\begin{array}{ccc}\text { Male } & 14 & 93 \% \\ \text { Female } & 1 & 7 \%\end{array}$




\begin{tabular}{ccc}
\hline Single & Marital status & $7 \%$ \\
Married & 1 & $93 \%$ \\
& 14 & \\
OND & Education & $66.7 \%$ \\
HND & 1 & $9.5 \%$ \\
BSC & 8 & $20 \%$ \\
MSC & 3 & $20 \%$
\end{tabular}

- The table above shows the demographic data of the respondents. It reveals that majority of the respondents are all professionals and their qualifications are H.N.D 53.33\% and B.S.C $20 \%$ while M.S.C $20 \%$ and O.N.D 6.67\% respectively.

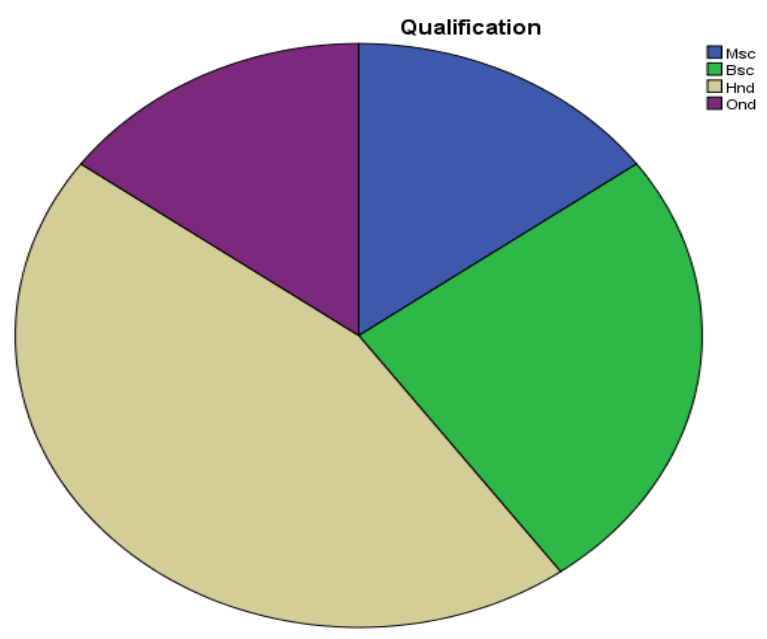

Table 2 Research Question 1: What method of Valuation is most appropriate for valuing Specialized Property? This subsection reports the findings of Research Objective 1;

Level of Agreement and Disagreement with the Statement on the Reliability of Depreciated Replacement Cost Compared to Other Valuation Methods.

\begin{tabular}{|c|c|c|c|c|c|c|c|}
\hline $\begin{array}{l}\text { Depreciated Replacement Cost is the most } \\
\text { reliable in Valuing Specialized Property. }\end{array}$ & $\begin{array}{l}\text { SA } \\
14\end{array}$ & $\bar{A}$ & $\begin{array}{l}\mathrm{U} / \mathrm{N} \\
0\end{array}$ & $\mathrm{D}$ & $\begin{array}{l}\mathrm{SD} \\
0\end{array}$ & $\begin{array}{l}\text { AWM } \\
4.93\end{array}$ & $\begin{array}{c}\text { RANK } \\
1\end{array}$ \\
\hline $\begin{array}{l}\text { Comparative Method is the most reliable in } \\
\text { Valuing Specialized Property }\end{array}$ & 0 & 0 & 6 & 8 & 1 & 2.33 & 2 \\
\hline $\begin{array}{l}\text { Investment Method is the most reliable in } \\
\text { Valuing Specialized Property }\end{array}$ & 0 & 0 & 0 & 1 & 14 & 1.07 & 5 \\
\hline $\begin{array}{l}\text { Profit or Account Method is the most reliable in } \\
\text { valuing Specialized Property }\end{array}$ & 0 & 0 & 1 & 1 & 13 & 1.20 & 4 \\
\hline $\begin{array}{l}\text { Residual Method is the most reliable valuing } \\
\text { Specialized Property }\end{array}$ & 1 & 0 & 1 & 2 & 11 & 1.53 & 3 \\
\hline
\end{tabular}

Key: SA, Strongly Agree, A= Agree UN= Undecided D=Disagree SD=Strongly Disagree. 


\section{International Journal of Engineering Applied Sciences and Technology, 2021 Vol. 6, Issue 2, ISSN No. 2455-2143, Pages 31-38 \\ Published Online June 2021 in IJEAST (http://www.ijeast.com)}

From the question answered by the respondents, 93\% strongly agreed that Depreciated Replacement Cost Method is most reliable Method of valuing Specialized Property, 7\% Agreed, 0\% Undecided 0\% Disagreed 0\% Strongly Disagreed.

Table 4 Research Question 2: How does the value of Ansarudeen Mosque be determined using Depreciated Replacement Cost Method of Valuation? This subsection reports the findings of research Objective 2; Using the Depreciated Replacement Cost Method to determine the value of Ansaru-deen Mosque Ilorin, Kwara State.

Description of the Property

The subject property of Ansarudeen Central Mosque covers approximately 38,85x28.90=1,122.765 $\mathrm{m}^{2}$ square meter. The land is in a good area. And it is very ripe with the fact that it was situated at Ibrahim Taiwo Road, Ilorin, Kwara State. The land is rectangular in shape and has good road accessibility and it is a two storey Building. The walls are of sandcrete block rendered and painted with Texcote Paint. The floor is constructed of tiles and has a flush door.

Table 3: Description and Condition of the Buildings in the Study Area

\begin{tabular}{|l|l|l|}
\hline S/No. & Decryption of Item & Condition of Building \\
\hline 1. & 2 No. Open Ground & Well furnished and maintained. \\
\hline 2. & 1 No. Ablution Ground & In a fairly state of decorative repair. \\
\hline 3. & 1 No. Corpse Bathroom & In a good state of decorative repair. \\
\hline 4 & Wall Fencing & $\begin{array}{l}\text { 2.1m height wall, partially rendered } \\
\text { and painted }\end{array}$ \\
\hline
\end{tabular}

Field Survey 2015.

\section{Constructional Details}

$>$ Roof: The buildings have mainly corrugated asbestos sheets on timber trusses.

$>$ Ceiling: These are mainly asbestos flat sheets. The administrative block has acoustic ceiling tiles, while the new extension has soft fit of reinforced concrete decking covered with fine prefab components.

Walls: Sandcrete block walls, rendered, plastered and painted on all faces.

$>$ Windows: These are mainly of glazed aluminum sliding frames.

$>$ Doors: These are a combination of flush doors. Cryptal hope casement and glazed aluminum sliding doors.

Floor: Concrete slab finished in a combination of cement/sand screed covered with soft carpet, ceramic floor tiles and P.V.C. floor tiles.

\section{Opinion of Value}

The study is of the considered professional opinion that the open Market Value of Ansarudeen Mosque, appraised and valued as at $23^{\text {rd }}$ August, 2015 is in the sum of $¥ 101,634,130.00$ (One Hundred and One Million, Six Hundred And Thirty Four Thousand One Hundred and Thirty Naira Only). This is made up as follows:

$>$ Land: N4, 000,000 (Four Million Naira Only).

$>$ Mosque=\$66,804,517 Sixty Six Million, Eight Hundred and Four Thousand Five Hundred and Seventeen Naira Only)

$>$ Corpse Bath Room: N539, 878 (five Hundred and thirty Nine Thousand eight Hundred and Seventy Eight Naira Only).

$>$ Open Ground 1: $\mathbf{N 0 5 , 4 5 0}$ (four Hundred and five Thousand Four Hundred and fifty Naira Only).

$>$ Open Ground 2: \$806, 400 \{Eight Hundred and Six Thousand Four hundred Naira Only\}.

$>$ Ablution Ground: $\mathbf{N 4}, \mathbf{7 0 8 , 9 3 5}$ \{four million seven Hundred and eight Thousand Nine hundred and thirty five Naira Only\}.

$>$ Fence $\mathbf{N 1 , 8 6 8 , 9 5 0}$ (One Million, Eight Hundred and Sixty Eight Thousand Nine Hundred and Fifty Naira only).

$>$ External work $\mathbf{N 1 , 0 0 0 , 0 0 0 ( O n e ~ M i l l i o n ~ N a i r a ~ O n l y ) . ~}$

Table 4: A Break Down of Value of Land and Improvements

\begin{tabular}{l|l|l} 
S/NO & Description of item & Value arrived at $(\mathbf{N})$
\end{tabular}


International Journal of Engineering Applied Sciences and Technology, 2021

Vol. 6, Issue 2, ISSN No. 2455-2143, Pages 31-38

Published Online June 2021 in IJEAST (http://www.ijeast.com)

\begin{tabular}{|c|c|c|c|}
\hline \multirow[t]{6}{*}{1} & \multirow[t]{6}{*}{ Mosque } & \multicolumn{2}{|c|}{$38,85 \times 28.90=1,122.765 \mathrm{~m}^{2}$} \\
\hline & & Cost of Construction $/ \mathrm{m}^{2}$ & $\$ \underline{35,000}$ \\
\hline & & Cost of Building & N $39,29 \overline{6,775}$ \\
\hline & & \multicolumn{2}{|c|}{$\begin{array}{c}X 2 \\
\$ 78,593,550\end{array}$} \\
\hline & & Less Depreciation & .85 \\
\hline & & Value arrived at & 66,804,517 \\
\hline \multirow[t]{5}{*}{2} & \multirow[t]{5}{*}{ Corpse Bath Room } & Corpse Bath Room & $19.19 \mathrm{~m}^{2}$ \\
\hline & & Cost of Construction $/ \mathrm{m}^{2}$ & N 30,000 \\
\hline & & Cost of Building & N $\overline{596,865}$ \\
\hline & & Less Depreciation & .90 \\
\hline & & Value arrived at & \$539,878 \\
\hline \multirow[t]{5}{*}{3} & \multirow[t]{5}{*}{ Open Ground 1} & Open Ground 1 & $135.15 \mathrm{~m}^{2}$ \\
\hline & & Cost of Construction $/ \mathrm{m}^{2}$ & $\mathbf{N} 30,000$ \\
\hline & & Cost of Building & $\mathbf{\$ 0 5 , 4 5 0}$ \\
\hline & & Less Depreciation &.$\underline{10}$ \\
\hline & & Value arrived at & $\mathbf{N} 405, \overline{450}$ \\
\hline \multirow[t]{5}{*}{4} & \multirow[t]{5}{*}{ Open Ground 2} & Open Ground 2 & $224.00 \mathrm{~m}^{2}$ \\
\hline & & Cost of Construction $/ \mathrm{m}^{2}$ & $\mathbf{N 3 0 , 0 0 0}$ \\
\hline & & Cost of Building & $\mathbf{N} 6,7 \overline{20,000}$ \\
\hline & & Less Depreciation & .12 \\
\hline & & Value arrived at & $\mathbf{N} 806, \overline{400}$ \\
\hline \multirow[t]{5}{*}{5} & \multirow[t]{5}{*}{ Ablution Ground } & Ablution Ground & $149.49 \mathrm{~m}^{2}$ \\
\hline & & Cost of Construction $/ \mathrm{m}^{2}$ & $\mathbf{N 3 5 , 0 0 0}$ \\
\hline & & Cost of Building & $\mathbf{N 5 , 2 3 2 , 1 5 0}$ \\
\hline & & Less Depreciation &.$\underline{90}$ \\
\hline & & Value arrived at & 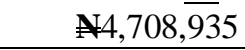 \\
\hline \multirow[t]{5}{*}{6} & \multirow[t]{5}{*}{ Fence } & fence & 255 \\
\hline & & Cost of Construction $/ \mathrm{m}^{2}$ & $\underline{8,143.575}$ \\
\hline & & Cost of Building & $\$ 2,076,611.625$ \\
\hline & & Less Depreciation &.$\underline{.90}$ \\
\hline & & Value arrived at & 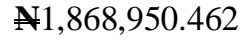 \\
\hline \multirow[t]{3}{*}{7} & \multirow{3}{*}{$\begin{array}{c}\text { External work } \\
\text { Land Value }\end{array}$} & \multicolumn{2}{|c|}{$\$ 500,000$} \\
\hline & & \multicolumn{2}{|c|}{$\# 4,000,000$ Per Plot } \\
\hline & & 6 and half Plots & $\$ 26,0000,000$ \\
\hline
\end{tabular}

Table 5 Research Question 3: This subsection reports the findings of Research Question 3; What are the challenges associated with valuation of specialized property. This subsection reports the findings of Research Objective 3;

Challenges associated with valuation of specialized property

\begin{tabular}{|c|c|c|c|c|c|}
\hline They are rarely sold or let and sold. & SA & A & UN & D & SD \\
\hline $\begin{array}{c}\text { Lack of specific information about the existing } \\
\text { sales to make essential adjustment and draw a } \\
\text { reasonable valuable conclusion. }\end{array}$ & 15 & 0 & 0 & 0 & 0 \\
\hline
\end{tabular}


International Journal of Engineering Applied Sciences and Technology, 2021

Vol. 6, Issue 2, ISSN No. 2455-2143, Pages 31-38

Published Online June 2021 in IJEAST (http://www.ijeast.com)

\begin{tabular}{|c|c|c|c|c|c|}
\hline $\begin{array}{c}\text { Values cannot be established by the normal } \\
\text { interplay of the market forces of Demand and } \\
\text { Supply. }\end{array}$ & 13 & 2 & 0 & 0 & 14 \\
\hline Rate of depreciation used may be inadequate. & 0 & 0 & 1 & 1 & 13 \\
\hline $\begin{array}{c}\text { They are not easy to convert to other uses other } \\
\text { than run as Business Concern. }\end{array}$ & 1 & 0 & 1 & 2 & 11 \\
\hline
\end{tabular}

Key: SA, Strongly Agree, A= Agree UN= Undecided D=Disagree SD=Strongly Disagree.

From the question answered by the respondents, $100 \%$ are of the opinion that the great issue facing the valuation of specialized property is that specialized property are rarely sold or let and such property lack evidence of recent sales transaction.

\section{CONCLUSION}

This study compared the accuracy of using the depreciated replacement cost approach to other approaches in valuing the specialized property Ansarudeen Mosque. This research has some practical consequences. The Depreciated Replacement Cost Method is better suited for valuing Mosque, according to the report, which is based on means score rating. Moreover, the mosque's special existence and distinction as a specialized property has been the decisive factor in determining that the Depreciated Replacement Approach is the best method of valuation. As a result, when valuing similar religious property, the Estate Surveyor and Valuer should pay close attention to the issues concerning the valuation of specialized property.

\section{RECOMMENDATION}

When valuing specialized property, the decrease of value that occurs as buildings and other types of improvements age and depreciate becomes increasingly difficult to measure accurately. For proper cost advice, a valuer should always pursue the services of a Quantity Surveyor and other cost consultant. Construction unit cost guidelines should be made available.

\section{REFERENCES}

1 Abidoye, R. B., Junge, M., Lam, T. Y., Oyedokun, T. B., \& Tipping, M. L. (2019). Property valuation methods in practice: evidence from Australia. Property Management.

2 Babawale, G. K. (2009), Towards a Standardized Approach to Real Estate Valuation Practice in
Nigeria, Journal of the Nigerian Institution of Estate Surveyors and Valuers, 32 (1), (pp. 18-28).

3 Babawale, G. K., \& Oyalowo, B. A. (2011). Incorporating sustainability into real estate valuation: The perception of Nigerian valuers.

4 Babawale, G. K., Koleoso, H. A., \& Otegbulu, C. A. (2012). A hedonic model for apartment rentals in Ikeja area of Lagos metropolis. Mediterranean Journal of Social Sciences, 3(3), (pp. 109-119).

5 Baum, A. E., Crosby, N., \& Devaney, S. (2021). Property investment appraisal. John Wiley \& Sons

6 Bellman, L., \& Lind, H. (2019). Valuation standards and methods: are Sweden's (still) different?. Journal of European Real Estate Research.

7 Bello, M .O. \& Bello, V. A. (2007), The Influence of Contemporary Models on Valuation Practice in Nigeria, Hong Kong SAR, TS 3C- Valuation Practice, Strategic Intergration of Survey of Services, FIG Week, (pp. 13-17).

8 Carson, R. (2012). Contingent valuation: $a$ comprehensive bibliography and history. Edward Elgar Publishing.

9 Ellsworth, R. (2001).The Sales Comparison Approach and The Appraisal of Complete Facilities.The appraisal Journal, July 2001, (pp. 266-269).

10 Fischer, D. (2002).Property Valuation Methodology, Black Ant Press.

11 Fourcade, M. (2011). Cents and sensibility: economic valuation and the nature of "nature". American journal of sociology, 116(6), 1721-77.

12 Ifediora, G. S. A. (2009). Appraisal Framework, $2^{\text {nd }}$ Edition, Enugu: Institute for Development Studies.

13 Hamilton, T. W. (2013). Economic rationale, highest and best use, and market valuation issues 


\section{International Journal of Engineering Applied Sciences and Technology, 2021 \\ Vol. 6, Issue 2, ISSN No. 2455-2143, Pages 31-38 \\ Published Online June 2021 in IJEAST (http://www.ijeast.com)}

for appraising inextricably intertwined assets. Real Estate Issues, 38(2) (pp.18-26)

14 Johnson, J., Davies, K. \& Shapiri, E. (2000), Modern Methods of Valuation of Land, Houses and Buldings, $9^{\text {th }}$ Edition, London: Estate Gazette, E. P. P. Books Services.

15 Kuye, G. O. (2000), Property Valuation Principle and Practice in Nigeria, Lagos: National Library Cataloguing in Publication Data.

16 Mackmin, D., \& Sams, G. (2012). Modern Methods of Valuation. Taylor \& Francis.

17 Millington, A. F. (1988), Introduction to Property Valuation, London: The Estate Gazette limited.

18 Ogunba, O. A. (2013), Principles and Practice of Property Valuation in Nigeria, Ibadan: Atlantis Books.

19 Onyejiaka, J. C., Oladejo, E. I., \& Emoh, F. I. (2015). Challenges of using the cost method of valuation in valuation practice: A case study of selected residential and commercial properties in Awka and Onitsha, Anambra State, Nigeria. International Journal of Civil Engineering, Construction and Estate Management, 3(2), (pp. 16-35).

20 Parr, R. L. (2018). Intellectual property: valuation, exploitation, and infringement damages. John Wiley \& Sons.

21 Royal Institute of Chartered Surveyors (RICS) (2005), RICS Appraisal and Valuation Standards (The Red Book), London: Authors.

22 Wyatt, P. (2013). Property valuation. John Wiley $\&$ Sons. 